\title{
The diatom genus Gomphonema Ehrenberg in India: Checklist and description of three new species
}

\section{B. Karthick ${ }^{1}$, J.P. Kociolek ${ }^{2}$, M.K. Mahesh $^{3}$ and T.V. Ramachandra ${ }^{1}$}

${ }^{1}$ Energy and Wetlands Research Group, Centre for Ecological Sciences, Indian Institute of Science, Bangalore 560 012, India

${ }^{2}$ Museum of Natural History and Department of Ecology and Evolutionary Biology, University of Colorado, Boulder, CO, USA

${ }^{3}$ Department of Botany, Yuvaraja's College, University of Mysore, Mysore - 570 005, India

With 51 figures and 2 tables

Karthick, B., J.P. Kociolek, M.K. Mahesh \& T.V. Ramachandra (2011): The diatom genus Gomphonema Ehrenberg in India: Checklist and description of three new species. - Nova Hedwigia 93: 211-236.

Abstract: We have compiled a checklist of Gomphonema Ehrenberg taxa reported previously from India. From forty-nine references, over 100 Gomphonema taxa have been reported, including 39 new taxon descriptions. In addition to these previous reports of Gomphonema taxa, we describe three new species, G. gandhii Karthick \& Kociolek, sp. nov., G. difformum Karthick \& Kociolek, sp. nov. and G. diminutum Karthick \& Kociolek, sp. nov., all from hill streams of Western Ghats, India. Frustule morphology, as studied in light and scanning electron microscopy, is compared with that of other recently described Gomphonema species from Africa and Asia. All three Indian species have distinctly dilated proximal raphe ends, in addition to differentiated apical pore fields, septa, pseudosepta and a round external stigmal opening. Gomphonema gandhii is linear-lanceolateclavate, has a wide axial area, and is 19-51 $\mu \mathrm{m}$ long, 3-7 $\mu \mathrm{m}$ broad. Gomphonema difformum is smaller than G. gandhii, and has a hyaline area around the headpole. Gomphonema diminuta is much smaller and narrower than the other two species. These species are distinct from their closest congeners by their sizes, shape and structure of the head pole, and striae densities. All these species were described from low nutrient, neutral, low ionic content streams of Western Ghats. As most other species described from tropical region these three species appear to be endemic to India. Moreover, within India they have hitherto only been found in Western Ghats, one of the twelve biodiversity hotspots of the World.

Key words: Bacillariophyceae, diatoms, Gomphonema, India, new species, taxonomy, valve ultrastructure.

*Corresponding author, email: patrick.kociolek@ colorado.edu

(C) 2011 J. Cramer in Gebr. Borntraeger Verlagsbuchhandlung, Stuttgart, Germany www.borntraeger-cramer.de DOI: $10.1127 / 0029-5035 / 2011 / 0093-0211$

0029-5035/2011/0093-0211 \$6.50 


\section{Introduction}

The diatom genus Gomphonema Ehrenberg is large, including over 500 taxa worldwide (Fourtanier \& Kociolek 2009). While its members are almost exclusively freshwater in terms of habitats, and many species are associated with impacted trophic levels (e.g. Patrick in Patrick \& Reimer 1966), the genus is quite diverse morphologically. Variation in valve ultrastructure includes presence or absence of stigmata, areolar structure, structure and position of the apical pore fields, and presence/absence of spines to name a few (Kociolek \& Stoermer 1993, but also see Metzeltin \& Lange-Bertalot 1998, Reichardt 1999). While some species of Gomphonema appear to be cosmopolitan in their distribution (for example, it appears that G. parvulum (Kützing) Kützing has been reported from all continents on earth), there are many reports of endemic species of Gomphonema from South America (Fricke 1904; Metzeltin \& Lange-Bertalot 2007), Africa (Compère 1995, Hustedt 1949, Kociolek \& Stoermer 1991), Madagascar (Spaulding \& Kociolek 1998), North America (Kociolek \& Kingston 1999, Thomas et al. 2009), Europe (Hustedt 1945, Reichardt 1999, 2005), Asia (Lange-Bertalot \& Genkal 1999, Li et al. 2006) and Australia and environs (Hustedt 1942, Kociolek et al. 2004).

India is a large, geographically complex country with ten different biogeographic zones covering over 3 million sq. km, about a third the size of all of Europe, but with nearly 50\% greater human population (World Population Prospects, 2008). The country shares borders with Bangladesh, Bhutan, Myanmar, China, Nepal and Pakistan. The complexity of India's freshwater environments includes three major, complex watersheds (Himalayas and the Karakoram ranges; Vindhya, Satpura ranges and the Chota Nagpur Plateau; and the Western Ghats) that cut across the country, related to their sources in the mountains. Freshwater environments range in elevation from sea level at the coast to over $8000 \mathrm{~m}$ above sea level.

The diatom genus Gomphonema in India has been documented for over 160 years. First report of the genus in India was by Ehrenberg (1845), who reported G. clavatum, G. gracile and G. turris from "Kolkatta" (then Calcutta) and River Ganges. Since then, 49 separate papers have identified 130 taxa of Gomphonema from India, mostly from lowland habitats. Of these, about $30 \%$ have been newly described taxa. In the region around India, gomphonemoid diatoms have been considered by Hustedt (1922), Jüttner et al. (2004) from Nepal, and Mereschkowsky (1906), Kociolek (1992), and $\mathrm{Li}$ et al. (2006, in press) from China. Though many species of Gomphonema have been described from India, there are extensive parts of the country that have not been investigated. The Western Ghats mountain range in Southern India, one of the Gondwanaland breakup landmasses, is amongst the most important hotspots of biodiversity. Western Ghats is a chain of mountains that runs parallel with the west coast of India for over $1600 \mathrm{~km}$ from $8^{\circ} 15^{\prime} \mathrm{N}$ to $21^{\circ} 00^{\prime} \mathrm{N}$. Due to its distinct physiographic, edaphic and climatic gradients, this region harbors a wide array of habitats with unique geographic position and that support unique sets of flora and fauna. The Western Ghats harbors approximately 5000 species of vascular plants belonging to nearly 2200 genera; about 1700 species $(34 \%)$ are endemic. There are also 58 endemic plant genera, while nearly three-quarters of the endemic genera 


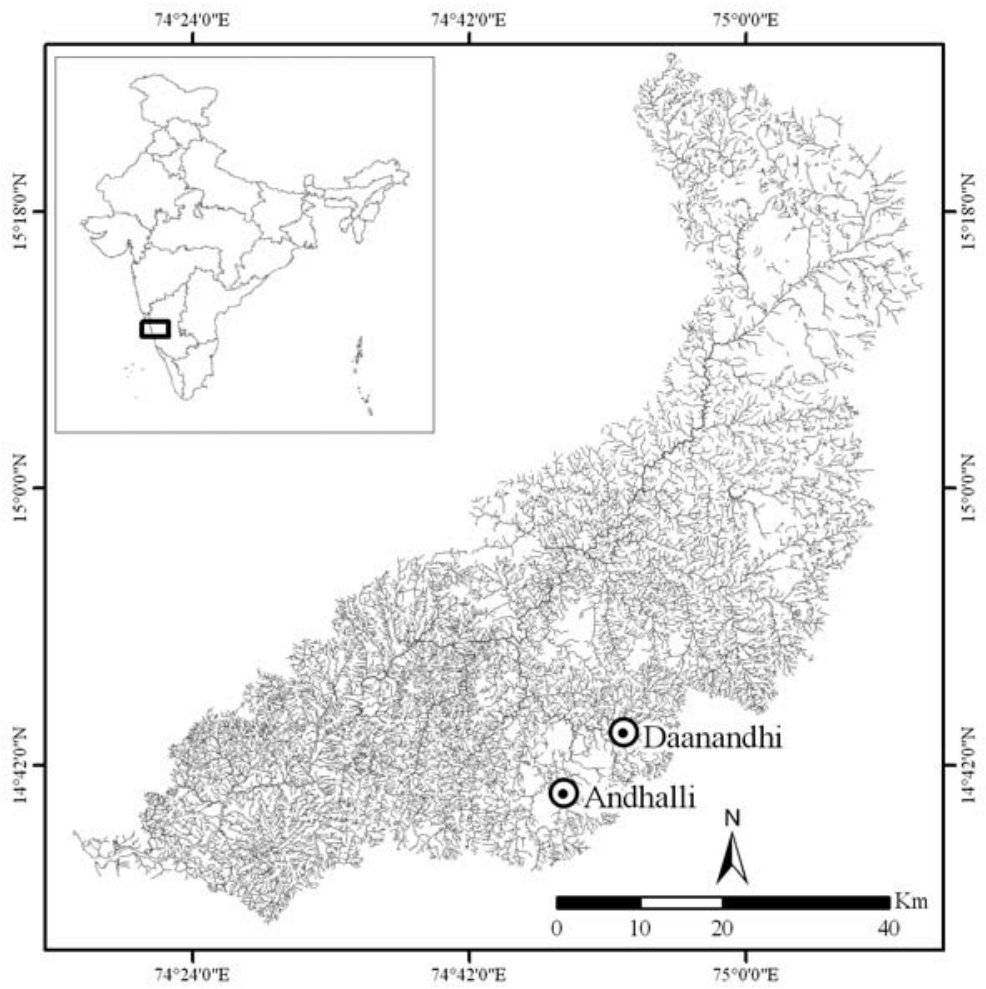

Fig 1. Map showing the area of investigation (inset India with Bedthi River basin highlighted).

have only a single species (Conservation International, 2008). The fauna and flora of this region has attracted attention of systematic and evolutionary biologists because of the mixture of high-level endemism (Inger, 1999; Myers et al. 2000) and various affinities with other biogeographic regions (Bossuyt \& Milinkovitch, 2001).

In the present report we have compiled a checklist of the Gomphonema taxa previously reported and described from India (Table 1). We also document and describe with light and scanning electron microscopy three new species of Gomphonema from Central Western Ghats, Karnataka State, India. We also present information about each species' autecology, with particular attention paid to water chemistry and seasonality.

\section{Materials and methods}

Ten first to fourth order streams were surveyed for diatoms and water quality assessment in the Bedthi River Basin, Central Western Ghats, Karnataka (Fig. 1) from January to December, 2006. Diatom samples were collected by vigorously scrubbing 3-5 stones from the substratum with a toothbrush and the resultant suspension was preserved in ethanol. A portion of sample was oxidized by the hot $\mathrm{HCl}$ and $\mathrm{KMnO}_{4}$ method (Taylor et al. 2007). Cleaned material was mounted onto glass slides with 
Table 1. Listing of Gomphonema taxa for India and references that have reported each taxon. (Note: $*$ denotes the species described from Indian administrative boundary; $\dagger$ indicates the studies on fossil material)

\section{Species name}

$1 \quad$ Gomphonema abbreviatum Kütz.

$2 \quad$ Gomphonema abbreviatum Kütz.

f. minor? Krishnamurthy*

3 Gomphonema abbreviatum Kütz. v. pulneyensis? Krishnamurthy*

4 Gomphonema acuminatum Ehr.

5 Gomphonema acuminatum Ehr.

v. elongata (Rabh.) W.Sm.

6 Gomphonema acuminatum Ehr. v. directum A.Cl.

7 Gomphonema acuminatum Ehr. v. turris (Ehr.) $\mathrm{Cl}$.

8 Gomphonema aequatoriale Hust.

9

Gomphonema angustatum (Kütz.) Rabh. v. producta Grun v. producta Grun. f. indica Gandhi*

\section{Gomphonema apicatum Ehr.}

Gomphonema augur Ehr.

Gomphonema augur Ehr. v. gautieri V.H

Gomphonema augur Ehr. v. genuinum

May.

Gomphonema balatonis Pant.

Gomphonema balatonis Pant. v. lanceolata Gandhi

Gomphonema brasiliense Grun.

Gomphonema bengalensis Grun*

Gomphonema bohemicum Reichelt

et Fricke

Gomphonema capitatum Ehr.

Gomphonema clavatoides Gandhi*

Gomphonema clavatoides Gandhi v. valida Gandhi*

Gomphonema clavatoides v. rostrata Gandhi*

Gomphonema clavatum Ehr.

Gomphonema clevei f. acuta Gandhi*

Gomphonema clevei Fricke

\section{Reference}

Abdul-Majeed 1935; Srinivasan 1965; Suxena and Venkateshwarlu 1970

Krishnamurthy 1954; Kumawat et al. 2008

Krishnamurthy 1954

Carter 1926; Biswas 1936; Krishnamurthy 1954 Biswas 1936

Gandhi 1959b

Krishnamurthy 1954; Gandhi 1960a; Sarode and Kamat 1980; Sarode and Kamat 1983; Sarode and Kamat 1984; Prasad and Srivastava 1992; Kumawat et al. 2008

Gandhi 1960a; Gandhi 1964; Sarode and Kamat 1980; Sarode and Kamat 1983; Sarode and Kamat 1984;

Kumawat et al. 2008

Gomphonema angustatum (Kütz.) Rabh. Krishnamurthy 1954; Srinivasan 1965; Kumawat et al. 2008

Krishnamurthy 1954; Kumawat et al. 2008

Gomphonema angustatum (Kütz.) Rabh. Gandhi 1960a; Sarode and Kamat 1984

Singh 1963

West and West 1907; Gandhi 1959a; Gandhi 1960a; Singh 1961; Gandhi 1962a; Gandhi 1966; Gandhi 1983a†; Sarode and Kamat 1984; Kumawat et al. 2008

Gandhi 1983a†

Gandhi 1956; Singh 1961; Singh 1963; Prasad and Srivastava 1992; Kumawat et al. 2008

Gandhi 1960a; Srinivasan 1965; Sarode and Kamat 1984; Kumawat et al. 2008

Gandhi 1960a; Sarode and Kamat 1984;

deToni 1891-94; Srinivasan 1965

deToni 1891-94;

Gandhi 1983a†

Abdul-Majeed 1935

Gandhi 1960a; Gandhi 1964; Srinivasan 1965; Gandhi 1966; Sarode and Kamat 1984; Prasad and Srivastava 1992; Gandhi 1998; Kumawat et al. 2008

Gandhi 1960a; Sarode and Kamat 1984

Gandhi 1998

Ehrenberg 1845

Gandhi 1966

Gandhi 1959b; Srinivasan 1965; Gandhi 1966; Prasad and Srivastava 1992 
Gandhi*

29 Gomphonema clevei v. javanica Hust.

30 Gomphonema clevei v. undulata Gandhi*

31 Gomphonema constrictum Ehr.

32 Gomphonema constrictum Ehr. v capitata (Ehr.) Cl.

33 Gomphonema constrictum Ehr. v. indica Gandhi*

34 Gomphonema constrictum Ehr. v. capitatum Cleve. f. italica Kuetz.

35 Gomphonema constrictum Ehr. v. capitatum Cleve. f. turgida Mayer Gomphonema dharwarensis Gandhi* Gomphonema dichotomum Kütz. Gomphonema dubia Meister Gomphonema dubravicense Pant. Gomphonema geminatum Ag. v. hybrida Grun.

42 Gomphonema gracile Ehr.

43 Gomphonema gracile Ehr. f. turris (Ehr.) Hust.

44 Gomphonema gracile Ehr. v. auritum A.Br.

45 Gomphonema gracile Ehr. v. dichotomum (W.Smith) Cleve

46 Gomphonema gracile Ehr. v. frickei Gandhi*

47 Gomphonema gracile Ehr. v. hybridum A.Cl.

$48 \quad$ Gomphonema gracile Ehr. v. intricatiforme May.

49 Gomphonema gracile Ehr. v. lanceolata (Kütz.) Cl.

50 Gomphonema gracile Ehr. v. major Grun.

51 Gomphonema gracile Ehr. v. naviculoides (W.Sm.) Grun.

52 Gomphonema gracile Ehr. v. subcapitata Gandhi*

53 Gomphonema grovei M.S

54 Gomphonema grovei M.S v. conspicua Gandhi et al.*
Gandhi 1966

Gandhi 1966

Abdul-Majeed 1935; Biswas 1936; Srinivasan 1965; Gandhi 1983a†; Kumawat et al. 2008

Gandhi 1960a; Gandhi 1983a†; Sarode and Kamat 1984; Kumawat et al. 2008

Gandhi 1960a; Sarode and Kamat 1984; Kumawat et al. 2008

Kumawat et al. 2008

Kumawat et al. 2008

Gandhi 1956; Srinivasan 1965

Ehrenberg 1845; Grunow 1865;

Meister 1932

Gandhi 1998

Gandhi 1983a†

Abdul-Majeed 1935

Ehrenberg 1845; Carter 1926;

Krishnamurthy 1954; Gandhi 1955; Gandhi 1957a; Gandhi 1959c; Gandhi 1960a; Gandhi 1962a; Singh 1962; Singh 1963; Gandhi 1966; Srinivasan 1965;

Sarode and Kamat 1984; Gandhi 1998; Kumawat et al. 2008

Sarode and Kamat 1984

Gandhi 1960a; Gandhi 1966; Sarode and Kamat 1983; Sarode and Kamat 1984; Prasad and Srivastava 1992 Thomas and Gonzalves 1965d

Gandhi 1960a; Sarode and Kamat 1984

Sarode and Kamat 1984

Sarode and Kamat 1983; Sarode and Kamat 1984

Krishnamurthy 1954; Gandhi 1960a; Sarode and Kamat 1984; Kumawat et al. 2008

Thomas and Gonzalves 1965b; Sarode and Kamat 1984; Kumawat et al. 2008

Gandhi 1960a; Gandhi 1962b; Sarode and Kamat 1983; Sarode and Kamat 1984; Kumawat et al. 2008 Sarode and Kamat 1984; Gandhi 1960a; Kumawat et al. 2008

Gandhi 1983a†; Gandhi 1998†

Gandhi 1983a†; Gandhi 1998†

Gandhi 1983a†; Gandhi 1998†

Gandhi 1983a†; Gandhi 1998†

Gandhi 1970; Sarode and Kamat 1980; Sarode and Kamat 1983 ; Sarode and Kamat 1984; Prasad and Srivastava 1992; Kumawat et al. 2008 
Table 1 continued.

\section{Species name}

58

59

Gomphonema intermedium Hust. Gomphonema intricatum Kütz.

60 Gomphonema intricatum Kütz. v. dichotoma (Kütz.) Grun.

61 Gomphonema intricatum Kütz. v vibrio $\mathrm{Cl}$. f. subventricosa Gandhi*

62 Gomphonema intricatum Kütz. v. bohemicum (Reich. et Fricke) A.Cl.

63 Gomphonema intricatum Kütz. v. fossile Pant.

64 Gomphonema intricatum Kütz. v. pumila Grun.

65 Gomphonema intricatum Kütz. v. pusillum May.

66 Gomphonema intricatum Kütz. v. vibrio (Ehr.) $\mathrm{Cl}$.

67 Gomphonema lacus-rankala Gandhi*

68 Gomphonema lacus-rankala Gandhi v. gracilis Gandhi*

69 Gomphonema lacus-rankala v. chandolensis Gandhi*

70 Gomphonema lacus-rankala Gandhi v. robusta Gandhi*

71 Gomphonema lapponicum A.Cleve 72 Gomphonema lanceolatum Ehr.

73 Gomphonema lanceolatum Ehr. v. insingis (Greg.) $\mathrm{Cl}$.

74 Gomphonema lanceolatum Ehr. f. turris (Ehr.) Hust.

75 Gomphonema lanceolatum Ehr. v. affine (Kütz.) A.Cl.

76 Gomphonema lingulatum Hust.

77 Gomphonema longiceps Ehr.

78 Gomphonema longiceps Ehr. v. subclavata Grun.

79 Gomphonema longiceps Ehr. v. subclavata Grun. f. gracilis Venkataraman*

80 Gomphonema macropunctatum Krishnamurthy*

81 Gomphonema magnifica Gandhi*

\section{Reference}

Prasad and Srivastava 1992

West and West 1907; Abdul-Majeed 1935; Krishnamurthy 1954; Gandhi 1958a; Gandhi 1960a; Gandhi 1983a†; Gandhi 1985†; Sarode and Kamat 1984; Gandhi 1998†

Gandhi 1983a†; Gandhi 1985†; Gandhi 1998†

Gandhi 1962b

Gandhi 1958a; Sarode and Kamat 1984

Sarode and Kamat 1980; Sarode and Kamat 1983;

Sarode and Kamat 1984

Singh 1962; Sarode and Kamat 1984

Sarode and Kamat 1983; Gandhi 1970; Prasad and Srivastava 1992

Venkataraman 1939; Gandhi 1959b; Gandhi 1960a; Sarode and Kamat 1980; Sarode and Kamat 1984;

Kumawat et al. 2008

Gandhi 1958a; Gandhi 1964; Srinivasan 1965; Sarode and Kamat 1984; Gandhi 1998

Gandhi 1962b; Gandhi 1964; Gandhi 1967; Gandhi 1970; Sarode and Kamat 1980; Sarode and Kamat 1984; Gandhi 1998; Kumawat et al. 2008

Gandhi 1964; Gandhi 1998; Kumawat et al. 2008

Gandhi 1958a; Sarode and Kamat 1980; Sarode and Kamat 1983; Sarode and Kamat 1984; Gandhi 1998; Kumawat et al. 2008

Kumawat et al. 2008

Grunow 1865; Carter 1926; Venkataraman 1939;

Gandhi 1958a; Gandhi 1959c; Gandhi 1960a; Gandhi 1960b; Gandhi 1962a; Gandhi 1962b; Gandhi 1964; Gandhi 1966; Gandhi 1967; Gandhi 1983at; Sarode and Kamat 1983; Sarode and Kamat 1984; Prasad and Srivastava 1992; Kumawat et al. 2008

Venkataraman 1939; Gandhi 1955; Gandhi 1960a; Gandhi 1966; Sarode and Kamat 1983; Sarode and Kamat 1984; Prasad and Srivastava 1992 Gandhi 1959b

Gandhi 1957b; Gandhi 1960b; Sarode and Kamat 1984

Gandhi 1960a; Sarode and Kamat 1984

Krishnamurthy 1954

Krishnamurthy 1954; Sarode and Kamat 1983

Venkataraman 1956

Krishnamurthy 1954; Srinivasan 1965

Gandhi 1960a; Srinivasan 1965; Sarode and Kamat 1984; Kumawat et al. 2008 
Gomphonema magnifica Gandhi v. rhomboida Gandhi*

83 Gomphonema major A.Cl.F. unipuncta A.Cl.

84 Gomphonema martini Fricke

85 Gomphonema moniliforme Gandhi*

86 Gomphonema montanum Schum

87 Gomphonema montanum Schum v. acuminatum May.

88 Gomphonema montanum Schum v. acuminatum May. f. indicum Sarode et Kamat*

Gomphonema montanum Schum v. acuminatum May. f. maharashtrensis Sarode et Kamat*

90 Gomphonema nagpurense Sarode et Kamat*

91 Gomphonema olivaceoides Hust.

92 Gomphonema olivaceum (Lung.) Kütz.

93 Gomphonema olivaceum (Lyng.)

Kütz. v. calcarea

94 Gomphonema olivaceum (Lyng.)

Kütz. v. balticum $\mathrm{Cl}$.

95 Gomphonema olivaceum (Lyng.) Kütz. Kumawat et al. 2008

v. genuinum Mayer. f. minutula Mayer

96 Gomphonema oregonicum Ehr.

97 Gomphonema parvulum (Kütz.) Grun.

Grunow 1865

Biswas 1936; Krishnamurthy 1954; Gandhi 1958a; Gandhi 1960a; Singh 1962; Singh 1963

Sarode and Kamat 1980; Gandhi 1985†; Sarode and Kamat 1984; Prasad and Srivastava 1992

Krishnamurthy 1954;

Krishnamurthy 1954; Gandhi 1956

Grunow 1865; Skvortzow 1935; Venkataraman 1939; Gandhi 1955; Gandhi 1957a; Gandhi 1958b; Gandhi 1959a; Gandhi 1959c; Gandhi 1960a; Gandhi 1960b; Singh 1961; Gandhi 1962a; Gandhi 1966; Gandhi 1967; Sarode and Kamat 1980; Sarode and Kamat 1983; Sarode and Kamat 1984; Prasad and Srivastava 1992; Gandhi 1998; Kumawat et al. 2008

98 Gomphonema parvulum (Kütz.) Grun. v. lagenula (Grun.) Hust.

99 Gomphonema parvulum (Kütz.) Grun v. micropus (Kütz.) Cl.
Gandhi 1960a; Gandhi 1962b; Gandhi 1966;

Sarode and Kamat 1983; Sarode and Kamat 1984;

Kumawat et al. 2008

Gandhi 1960a; Gandhi 1960b; Gandhi 1962b; Gandhi 1966; Sarode and Kamat 1983; Sarode and Kamat 1984; Prasad and Srivastava 1992

100 Gomphonema parvulum (Kütz.) Grun. Gandhi 1956; Gandhi 1957a; Gandhi 1958b; Gandhi v. subellipticum $\mathrm{Cl}$.

1960a; Gandhi 1960b; Gandhi 1966; Sarode and Kamat 1983; Sarode and Kamat 1984; Kumawat et al. 2008

101 Gomphonema parvulum (Kütz.) Venkataraman 1957

102 Gomphonema parvulum (Kütz.) v. exlissma Grun.

103 Gomphonema parvulum (Kütz.) V.H. v. genuinium May.

Gandhi 1959c; Gandhi 1962b; Gandhi 1964; Gandhi 1967; Sarode and Kamat 1983; Sarode and Kamat 1984; Prasad and Srivastava 1992; Gandhi 1998; Kumawat et al. 2008; Gandhi 1956 
Table 1 continued.

\section{Species name}

104 Gomphonema punctatum Krasske

105

106
Gomphonema sphaerophorum Ehr.

\section{Reference}

Kumawat et al. 2008

* Gandhi 1970

107 Gomphonema sphaerophorum Ehr. v. kolhapurense Sarode et Kamat*

108 Gomphonema sphaerophorum Ehr. v. subcapitata Venkatraman*

109 Gomphonema sphaerophorum $\mathrm{f}$. jogensis Gandhi*

110 Gomphonema spiculoides Gandhi*

111 Gomphonema spiculoides Gandhi v. major Gandhi*

112 Gomphonema subapicatum Fiitsch et Rich v. okamurae (Skv) Gandhi

113 Gomphonema subapicatum Fritsch et Rich

114 Gomphonema subcapitatum v. curta Fritsch et Rich

115 Gomphonema subclavatum Grun.

116 Gomphonema submalayense Gandhi*

117 Gomphonema substicature Fritsch v. stipitata

118 Gomphonema subtile Ehr.

119 Gomphonema subtile Ehr. v. malayensis Hust.

120 Gomphonema subventricosum Hust.

121 Gomphonema sumatrense Fricke

122 Gomphonema tenellum W.Sm.

123 Gomphonema tenuis Gandhi*

124 Gomphonema tergestinum (Grun.) Frickie

125 Gomphonema tropicale Brun

126 Gomphonema turris Ehr.

127 Gomphonema undulatum Hust.

128 Gomphonema varanasis Singh*

129 Gomphonema vastum Hust v elongata Skv.

130 Gomphonema vidarbhense Sarode et Kamat*
Krishnamurthy 1954; Gandhi 1957a; Gandhi 1958b; Gandhi 1959c; Gandhi 1960a; Gandhi 1964;

Srinivasan 1965; Gandhi 1966; Sarode and Kamat 1980; Sarode and Kamat 1983; Sarode and Kamat 1984; Prasad and Srivastava 1992; Kumawat et al. 2008

Sarode and Kamat 1984; Kumawat et al. 2008

Venkataraman 1939; Thomas and Gonzalves 1965a

Gandhi 1966

Srinivasan 1965; Gandhi 1960a; Sarode and Kamat 1984

Gandhi 1960a; Sarode and Kamat 1984

Gandhi 1960a; Sarode and Kamat 1984

Abdul-Majeed 1935; Gandhi 1956; Gandhi 1958a; Gandhi 1960a; Gandhi 1960b; Gandhi 1962b; Gandhi 1964; Gandhi 1966; Gandhi 1967; Sarode and Kamat 1984; Gandhi 1998

Abdul-Majeed 1935

Carter 1926; Abdul-Majeed 1935

Gandhi 1970

Abdul-Majeed 1935

Gandhi 1958b; Gandhi 1962a; Gandhi 1966; Sarode and Kamat 1984

Gandhi 1960a; Gandhi 1966; Gandhi 1970; Sarode and Kamat 1984; Prasad and Srivastava 1992

Gandhi 1962a; Gandhi 1966; Sarode and Kamat 1984; Prasad and Srivastava 1992

Gandhi 1960a; Sarode and Kamat 1984

Dickie G 1882; West and West 1907; Gandhi 1998

Gandhi 1960a; Srinivasan 1965; Sarode and Kamat 1984

Krishnamurthy 1954

Gandhi 1959b

Ehrenberg 1845; Grunow 1865

Gandhi 1960a; Sarode and Kamat 1984

Singh 1961

Gandhi 1958b

Sarode and Kamat 1984 
Naphrax mounting medium and observed with Olympus BX-51 light microscopes equipped with DIC and 1.4NA objectives. Digital images were taken with an Olympus DP-71 digital camera. Scanning electron microscopy was done with cleaned specimens air dried onto cover glasses, attached to aluminum stubs, sputter-coated with $10 \mathrm{~nm}$ of Au-Pd, and examined in high vacuum mode with a JSM-6480LV (LVSEM) at $15 \mathrm{kV}$, with a spot size of 15 , and a working distance of $8 \mathrm{~mm}$. SEM work was performed at the University of Colorado's Nanomaterials Characterization Facility. In India, SEM work was accomplished with cleaned material air-dried onto cover glasses and sputter coated with ca. $10 \mathrm{~nm}$ of Au-Pd. Coated material was viewed in a FEI Quanta 200 ESEM at Indian Institute of Science Nanoscience Initiative Facility. Terminology on the diatom valves follows Ross et al. (1979). For features found in the gomphonemoid diatoms, we follow the terminology and character descriptions of Kociolek \& Stoermer (1993). Water chemistry analysis were carried out as per the Standard methods for water and waste water analysis by American Public Health Association (APHA, 2005)

\section{Results}

\section{Gomphonema gandhii Karthick \& Kociolek, sp. nov.}

Figs 2-19

DESCRIPTIO: Valvae lineares ad lineares-lanceolatae clavatae apicibus rotundatis ad anguste-rotundatis ad fere acuminatae capitolo-polo. Area apicalis porellorum distincta ad baso-polo. Frustula aspectu cincturae cuneata. Striae continuae circa capitulum-polum. Longitudo 19-51 $\mu \mathrm{m}$. Latitudo 3-7 $\mu \mathrm{m}$. Area axialis lata linearis-lanceolata. Area centralis indistincta. Raphe lateralis undulata. Extrema proximales externi raphis dilatatae. Externum orificium stigmatis rotundatis. Striae punctatae leviter radiatae ad parallelae, $9-11 / 10 \mu \mathrm{m}$. Septa et pseudosepta prasentia ad polos.

DESCRIPTION: Valves linear- to linear-lanceolate-clavate, with apices rounded to narrowly-rounded to nearly acuminate at the headpole. Apical pore field distinct at the footpole. Frustules cuneate, striae are continuous around the headpole. Length 19-51 $\mu \mathrm{m}$, breadth 3-7 $\mu \mathrm{m}$. Axial area broad, linear-lanceolate. No distinct central area. Raphe lateral, undulate. External proximal raphe ends dilated. Stigmal opening is round. Striae are punctate, slightly radiate to parallel, 9-11/10 $\mu \mathrm{m}$. Septa and pseudosepta are present at the poles.

HoLOTYPE: CESH-5-1869, Centre for Ecological Science Herbarium Diatom Collection, Indian Institute of Science, Bangalore, INDIA.

IsoTyPES: BM 101392. The Natural History Museum, Department of Botany, London, UK and Diatom Collection, University of Colorado, Boulder, USA

Type Locality: A Stream at Kammani (1442' 47.52"N-74³5' 44.988"E); Altitude 109 m asl (meters above sea level), a tributary Bedthi River. Uttara Kannada District, Karnataka, India. (leg. Karthick, B. and D.M.Vishnu, January 2006)

ETYMOLOGY: Named in honor of H.P.Gandhi, for his outstanding contributions to diatom research in India.

In the SEM, the exterior of the valve is dominated by areolae with flaps that form c-shaped openings (Figs 10-13). The undulate raphe has dilated proximal ends, while the external ends are deflected onto the mantle in the same direction (opposite the side bearing the stigma) (Figs 10,13). The external stigmal opening is small and round (Figs 10,12). The apical pore field is separated from the striae, and composed of rounded porelli (Figs 10, 13, 15). Internally, a small central nodule, relatively large helictoglossae, pseudosepta and the raphe slit are visible (Figs 16, 17, 18, and 19). The central nodule has highly recurved raphe ends that terminate as tight loops. A flap extends from each side of the central nodule, obscuring part of the curvature 


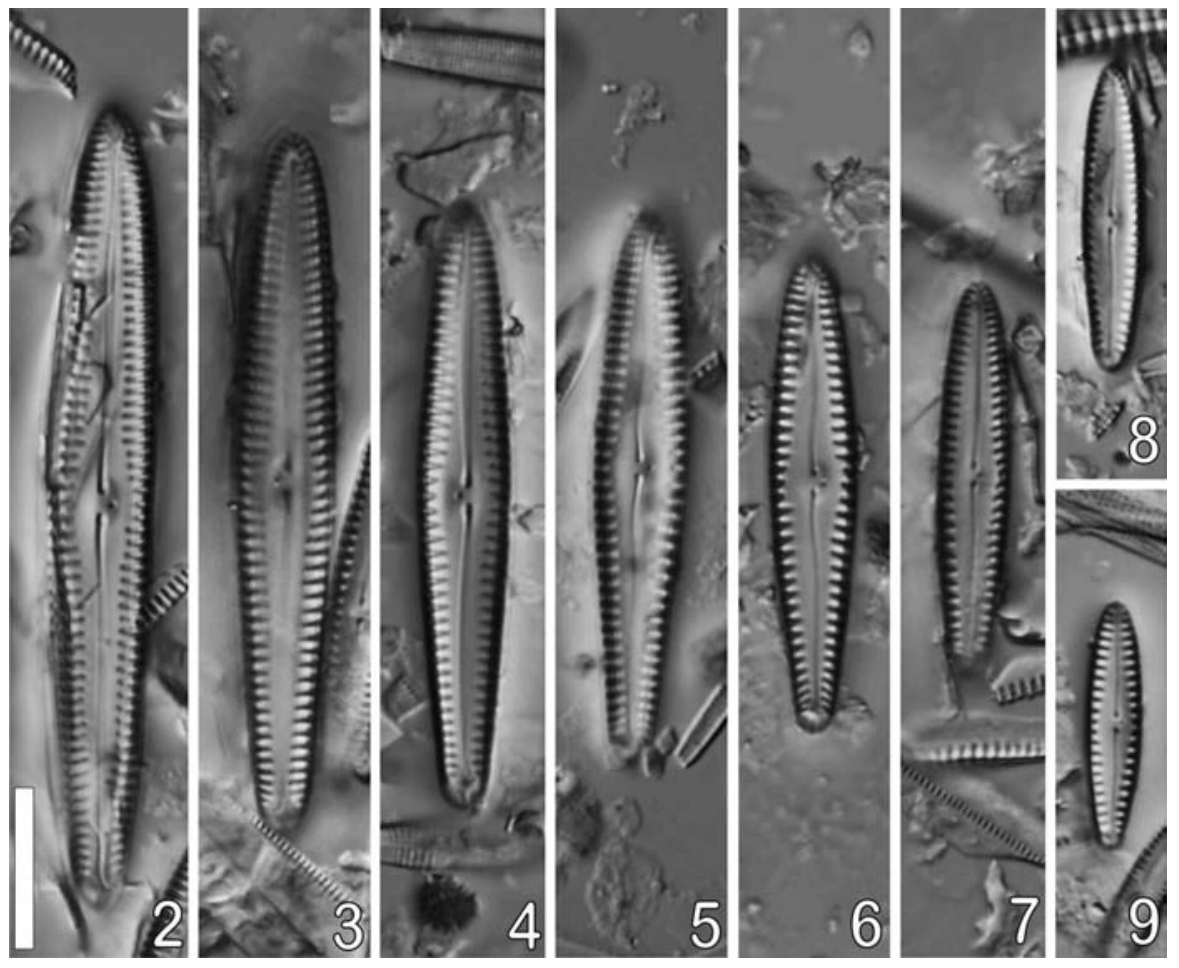

Figs 2-9. LM of Gomphonema gandhii, from the type population; valve views showing the size diminution series. Scale bar represents $10 \mu \mathrm{m}$.

of the raphe (Figs 16, 17, 19). A slit-like stigmal opening is present on the small central nodule (Figs 16, 17, 19). On either side of the valve interior, marginal laminae are present (Figs 16). Helictoglossae appear to be in line with each raphe branch (Figs 16, 18).

In girdle view, the apical pore field porelli are round, extending from the edge of the valve face and to the end of the mantle (Fig. 15). Bands are of the open type, and narrow; they follow the contour of the valve in girdle view. At the headpole the distal raphe end can be seen extending onto the mantle (Fig. 14). Areolae appear sunken into ellipsoidal depressions, in each of which is a flap (Figs 14, 15).

This species resembles both G. pararhombicum Reichardt, Jüttner \& Cox and G. incognitum Reichard, Jüttner \& Cox (Jüttner et al. 2004, p. 238). All three taxa have a similar valve outline and wide axial area. Gomphonema gandhii is more slender, has a narrower headpole and coarser striae than either of the species described from Nepal. The expanded concept of G. incognitum suggested by Reichardt (2005) is difficult to embrace, since specimens with very different valve shapes, sizes and striae densities have been considered conspecific. Coarser striae and more slender valves also distinguish G. gandhi from G. siamense Reichardt, and valve shape 


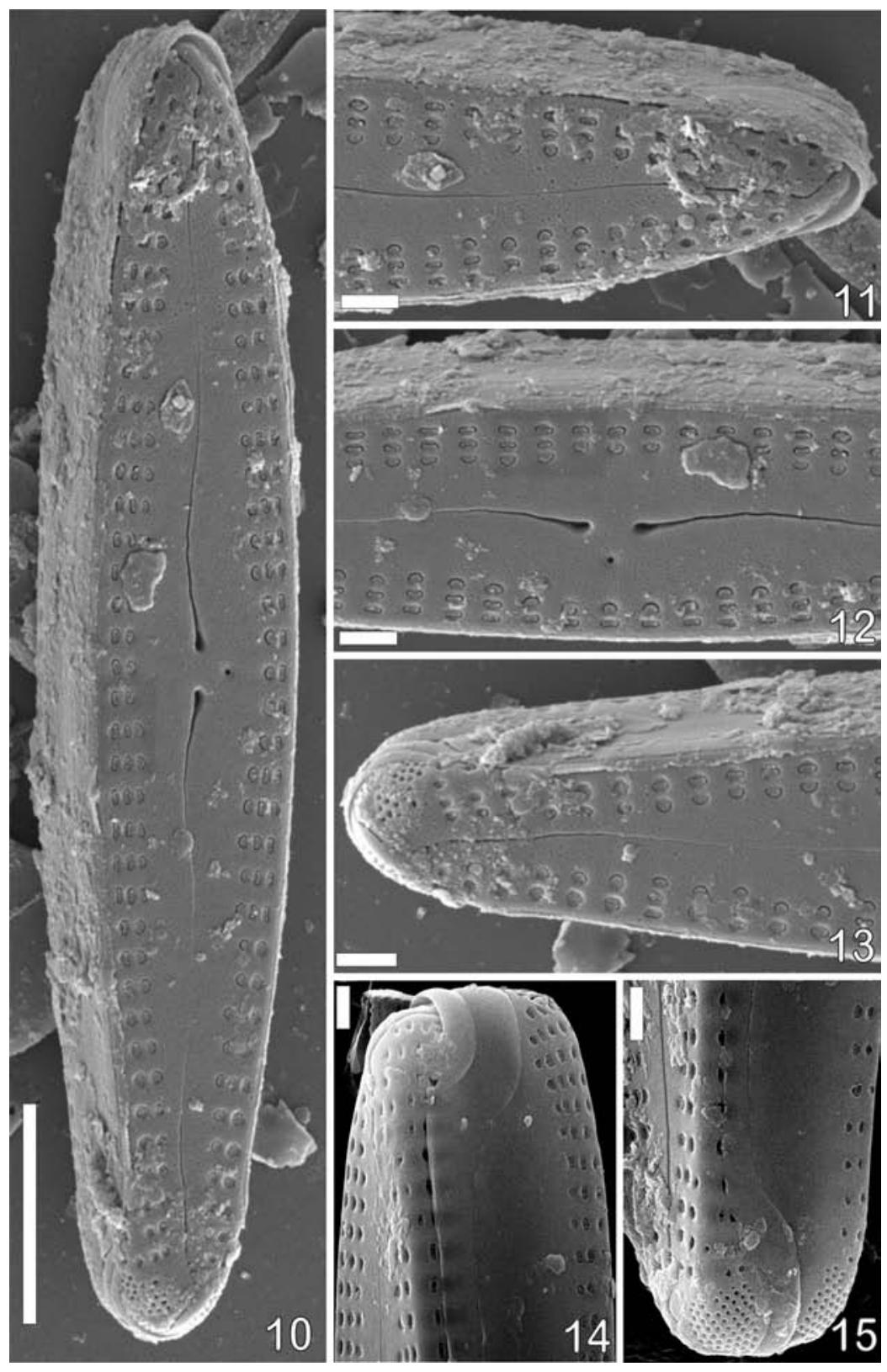

Figs 10-15. SEM. External view of Gomphonema gandhii. Fig. 10. Exterior view of whole valve. Fig. 11. Exterior of valve, headpole, with the external distal raphe end curving onto the valve mantle. Fig. 12. Exterior of valve center showing the stigma, dilated proximal raphe end and striae. Fig. 13. Exterior of valve showing the deflected apical end of raphe and rounded porelli. Fig. 14. Girdle view of the head pole showing the distal raphe end extending on to the mantle. Fig. 15 Girdle view of the foot pole with round apical pore field porelli. Scale bar represents $5 \mu \mathrm{m}$ (Fig. 10); $1 \mu \mathrm{m}$ (Figs 11, 12, 13, 14, 15). 


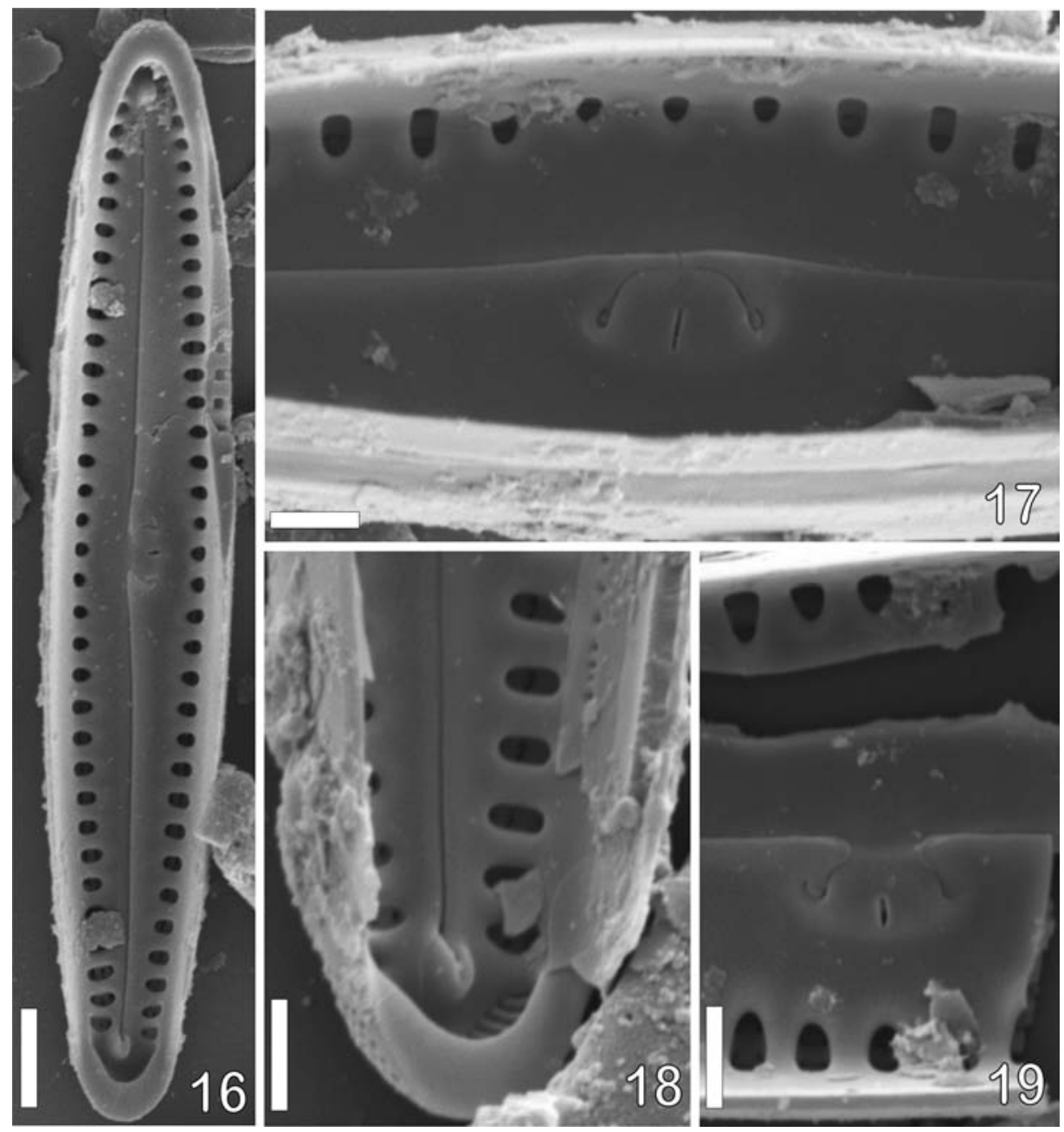

Figs 16-19. SEM. Internal view of Gomphonema gandhii. Fig. 16. Interior view of the whole valve showing the central nodule, large helictoglossae, pseudosepta and raphe slit. Fig. 17. Interior view of the center showing the central nodule, curvature of raphe and slit like stigmal opening. Fig. 18. Internal view showing the helictoglossae, pseudosepta and raphe slit. Fig. 19. Internal view of center showing the curvature of the raphe and slit-like stigmal opening. Scale bar represents $2 \mu \mathrm{m}$ (Fig. 16); $1 \mu \mathrm{m}$ (Figs $17,18,19)$.

(lacking the cuneate headpole) and coarser striae separate the Indian species from G. uniserhombicum Reichardt (2005).

ECOLOGY: Gomphonema gandhii is found throughout the central Western Ghats rivers. This species is present throughout the year, reaching maximum relative abundance $(60 \%)$ in September. The population of this species increases in winter season (Oct-Jan). This species occurs in abundance in many hill streams of central Western 
Table 2. Water Chemistry Characteristics (Mean \pm Standard Deviation) for the type localities measured from January to December 2006.

\begin{tabular}{lll}
\hline Water Chemistry Characters $($ Units) & Kammani & Andhalli \\
\hline pH & $7.08 \pm 0.17$ & $7.16 \pm 0.27$ \\
Water Temperature $\left({ }^{\circ} \mathrm{C}\right)$ & $26.66 \pm 2.20$ & $24.96 \pm 1.90$ \\
Electrical Conductivity $\left(\mu \mathrm{Scm}^{-1}\right)$ & $89.86 \pm 26.18$ & $79.71 \pm 11.12$ \\
Total Dissolved Solids $\left(\mathrm{mgl}^{-1}\right)$ & $44.62 \pm 13.09$ & $39.63 \pm 5.78$ \\
Air Temperature $\left({ }^{\circ} \mathrm{C}\right)$ & $30.54 \pm 2.94$ & $26.25 \pm 2.97$ \\
Free Carbon di oxide $\left(\mathrm{mgl}^{-1}\right)$ & $8.53 \pm 3.02$ & $9.83 \pm 3.55$ \\
Alkalinity $\left(\mathrm{mgl}^{-1}\right)$ & $33.27 \pm 16.29$ & $47.00 \pm 42.67$ \\
Chlorides $\left(\mathrm{mgl}^{-1}\right)$ & $13.00 \pm 3.17$ & $14.82 \pm 3.19$ \\
Hardness $\left(\mathrm{mgl}^{-1}\right)$ & $33.78 \pm 14.38$ & $28.87 \pm 4.16$ \\
Calcium $\left(\mathrm{mgl}^{-1}\right)$ & $7.32 \pm 3.34$ & $6.63 \pm 1.37$ \\
${\text { Magnesium }\left(\mathrm{mgl}^{-1}\right)}_{\text {Dissolved Oxygen }\left(\mathrm{mgl}^{-1}\right)}^{6.46 \pm 2.75}$ & $5.43 \pm 1.04$ \\
Phosphates $\left(\mathrm{mgl}^{-1}\right)$ & $7.88 \pm 1.40$ & $6.83 \pm 2.54$ \\
Nitrates $\left(\mathrm{mgl}^{-1}\right)$ & $0.04 \pm 0.02$ & $0.08 \pm 0.08$ \\
Sulphates $\left(\mathrm{mgl}^{-1}\right)$ & $0.29 \pm 0.37$ & $1.12 \pm 1.87$ \\
Sodium $\left(\mathrm{mgl}^{-1}\right)$ & $8.58 \pm 3.00$ & $21.09 \pm 26.94$ \\
Potassium $\left(\mathrm{mgl}^{-1}\right)$ & $7.62 \pm 2.26$ & $13.59 \pm 1.85$ \\
& $1.64 \pm 0.60$ & $3.15 \pm 1.17$ \\
\hline
\end{tabular}

Ghats region. This species occurs in circumneutral streams (pH: $7.08 \pm 0.17)$ with poor nutrients (Phosphate: $0.04 \pm 0.02 \mathrm{mgl}^{-1}$; Nitrates: $0.29 \pm 0.37 \mathrm{mgl}^{-1}$ ) and conductivity between $89.86 \pm 26.18 \mu \mathrm{Scm}^{-1}$ (see Table 2 ). The land cover in the catchment is characterized with wet evergreen to semi-evergreen forest type, and with least agricultural activities.

\section{Gomphonema difformum Karthick \& Kociolek, sp. nov.}

Figs 20-40

DESCRIPTIO: Valvae linearers-clavatae apicibus late rotundatibus ad quadratis ad capitolo-polo. Area apicalis porellorum distincta ad bsao-polo. Frustula cuneatum. Striae non-continuae circa capitulumpolum. Longitudo 19-32 $\mu \mathrm{m}$. Latitudo 4-6 $\mu \mathrm{m}$. Area axialis angusta dilatatescens dilute, faciens aream centralem linearem-ellipticalem. Raphe lateralis, dilute undulata. Extrema proximales externi raphis distincte dilatata. Striae aspectu costae, parallelae ad dilute radiatae 12-14/10 $\mu \mathrm{m}$. Externum orificium stigmatis parvum rotundatis praesens in aream centralem. Area bilobata unornata ad capitolo-polo. Septa et pseudosepta prasentia ad polos.

DESCRIPTION: Valves linear-clavate, apices broadly rounded to quadrate at the headpole. Apical pore field distinct at the footpole. Frustules cuneate. Striae do not appear continuous around headpole. Length 19-32 $\mu \mathrm{m}$, breadth 4-6 $\mu \mathrm{m}$. Axial area narrow, expanded slightly to form a linear-elliptical central area. Raphe lateral, weakly undulate. External proximal raphe ends distinctly dilated. Striae appear costate, parallel to weakly radiate, $12-14 / 10 \mu \mathrm{m}$. A small round stigmal opening is present in the central area. A bilobed unornamented area is present at the headpole. Septa and pseudosepta are present at both poles.

Holotyp: CESH-5-1870, Centre for Ecological Science Herbarium Diatom Collection, Indian Institute of Science, Bangalore, INDIA

Isotypes: BM 101393, The Natural History Museum, Department of Botany, London, UK. And Diatom Collection, University of Colorado, Boulder, USA. 

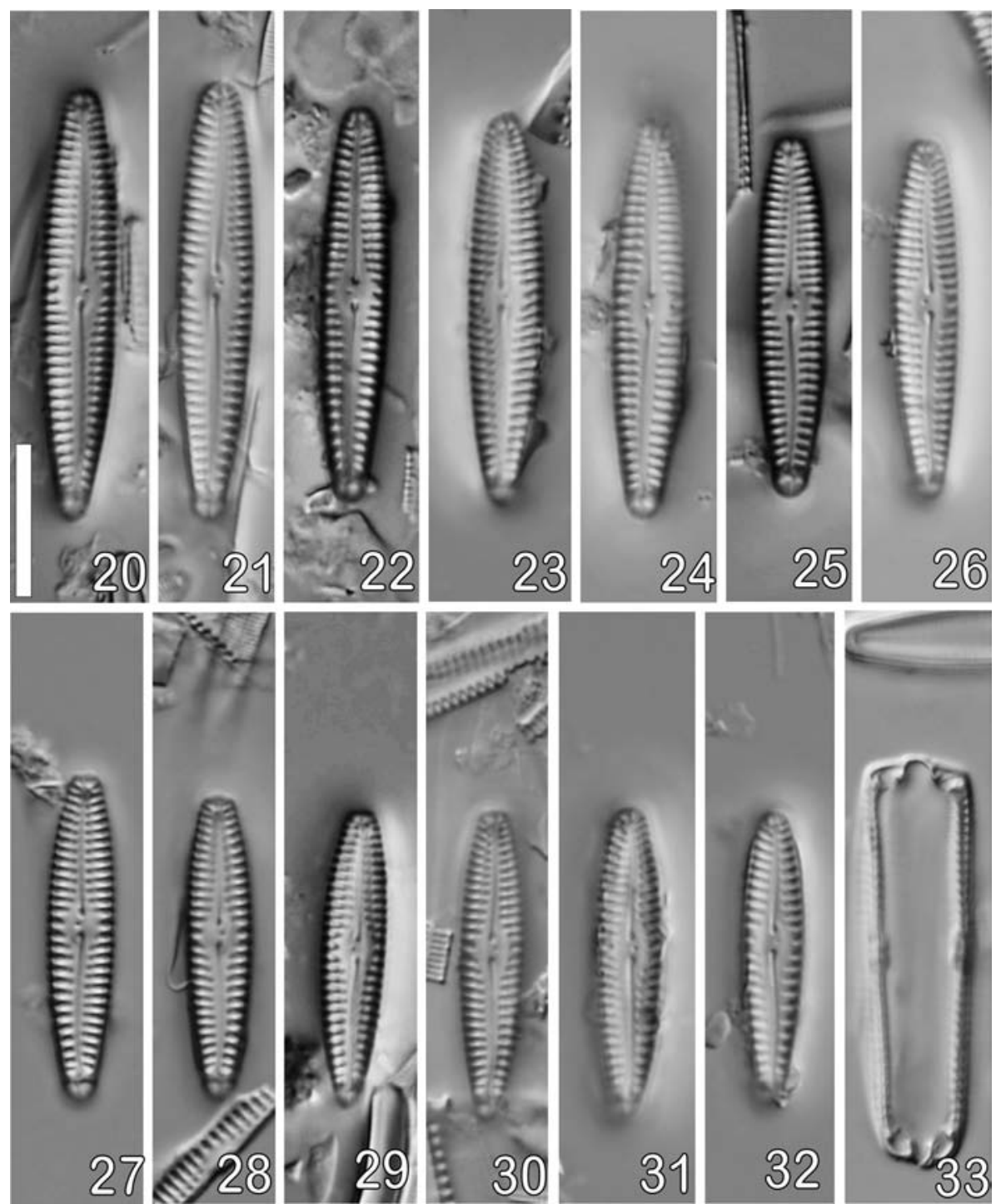

Figs 20 -32. LM of Gomphonema difformum, from the type population; valve view showing the size diminution series. Figure 33. Girdle view showing apical pore field like structures at both apices. Scale bar represents $10 \mu \mathrm{m}$.

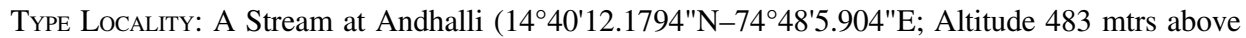
MSL), a tributary Bedthi River. Uttara Kannada District, Karnataka, India. (leg. Karthick, B. and D.M.Vishnu $-12^{\text {th }}$, January, 2006)

EтумоцоGy: The species epithet indicates the very different structure of this diatom relative to other members of the genus. 

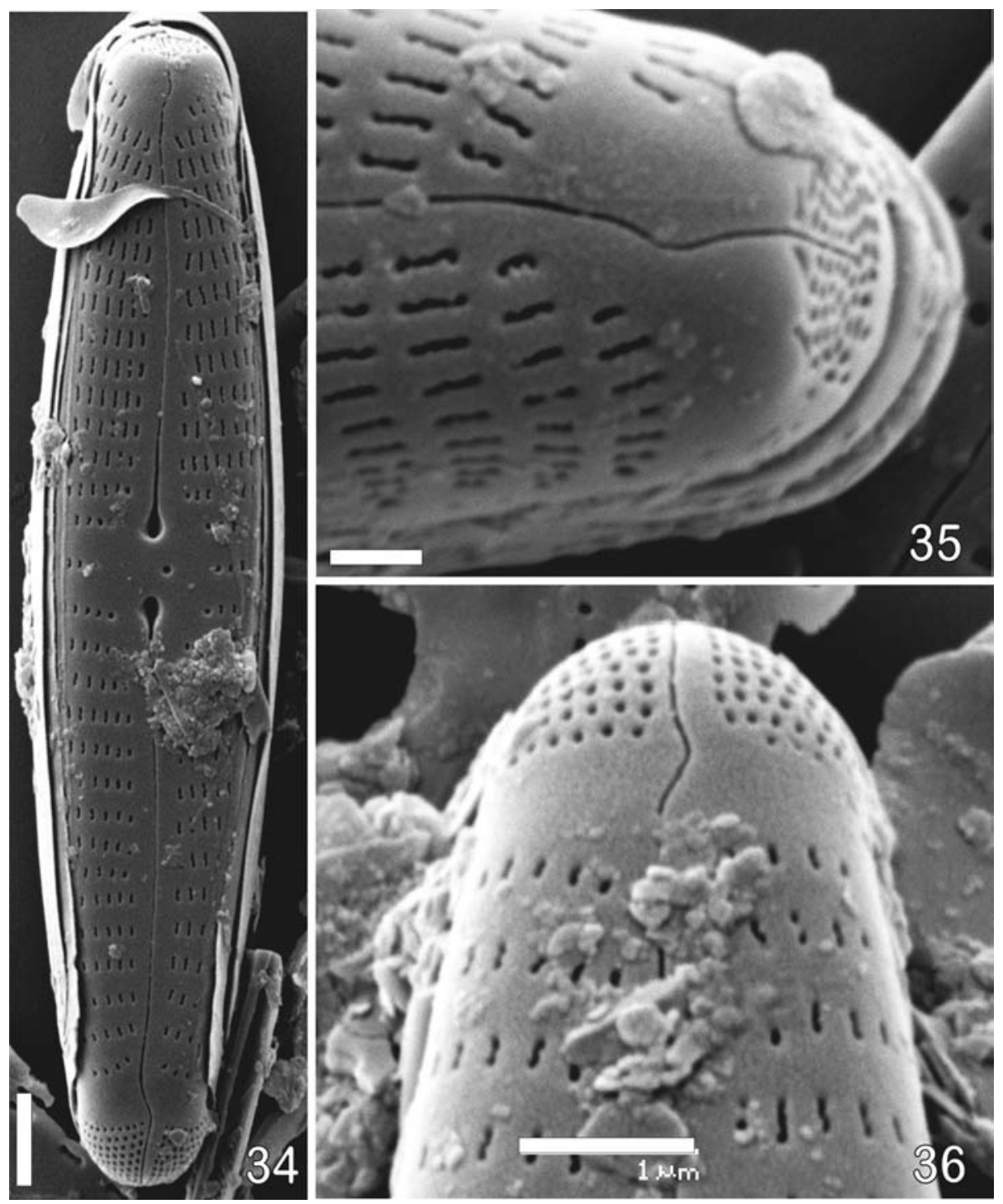

Figs 34-36. SEM. External view of Gomphonema difformum. Fig. 34. Exterior view of whole valve showing slit-like areolae, round stigma opening and undulate raphe with dilated proximal ends. Fig 35. Exterior view of the valve showing blunt headpole. Fig 36. Exterior view of the valve showing raphe bends onto the mantle, porelli and hyaline area which separates porelli from areolae. Scale bar represents $2 \mu \mathrm{m}$ (Fig. 34); $1 \mu \mathrm{m}$ (Fig. 36); $0.5 \mu \mathrm{m}$ (Fig. 35)

In the SEM, the valve exterior is dominated by slit-like areolae, a slightly undulate raphe with dilated proximal ends and a bilobed apical pore field (Figs 34-36). The central area has large, tear-dropped shaped proximal raphe ends and a small, round 


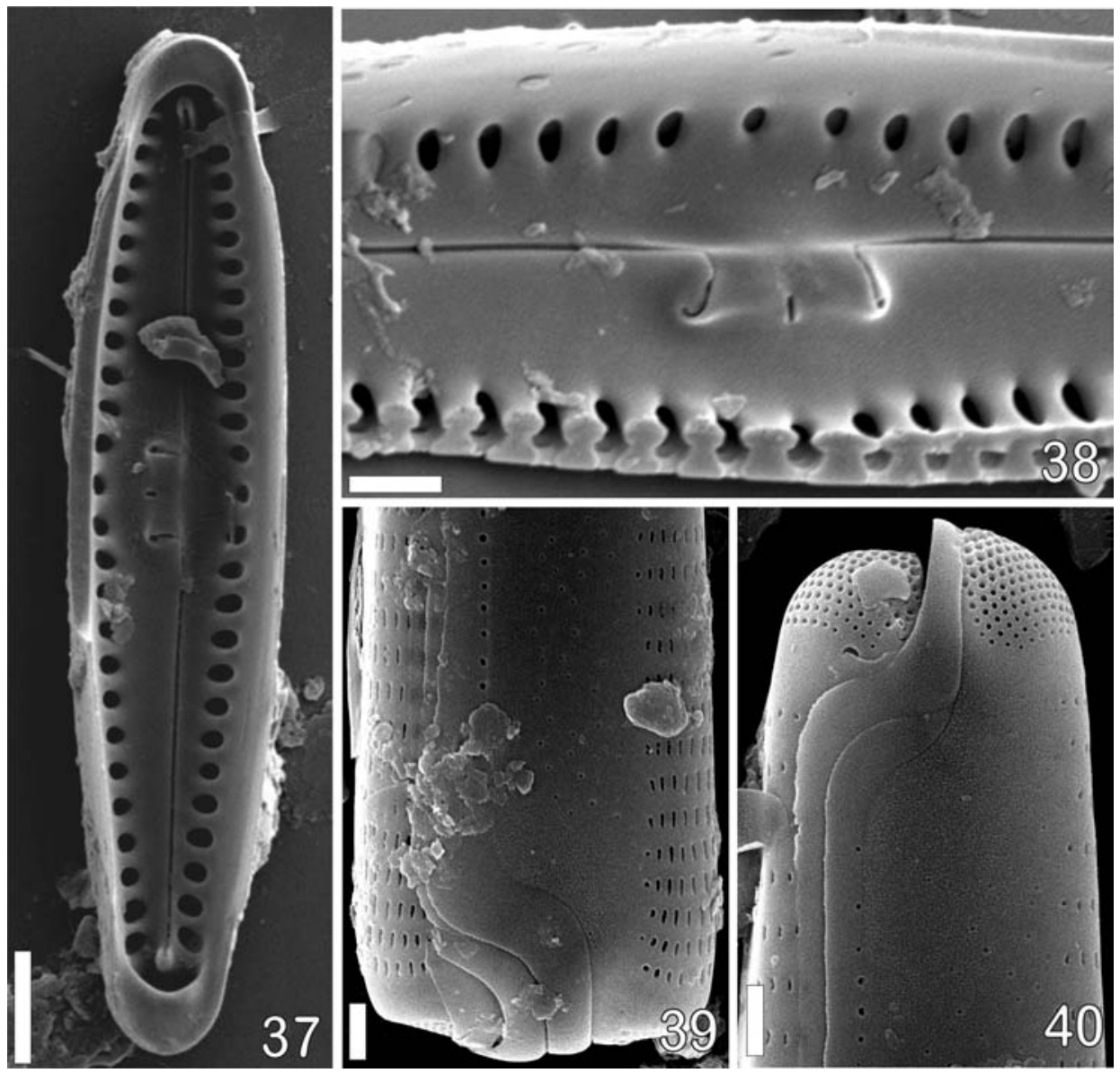

Figs 37-40. SEM. Interior and girdle view of Gomphonema difformum. Fig. 37. Interior view of the whole valve showing pseudosepta at both ends and large helictoglossae. Fig. 38. Interior view showing the central nodule with broadly recurved proximal raphe ends, rounded stigmal opening and marginal lamina. Fig. 39. Girdle view showing randomly distributed porelli on the mantle Fig. 40. Girdle view showing the open type bands with septa. Scale bar represents $2 \mu \mathrm{m}$ (Fig. 37); $1 \mu \mathrm{m}$ (Figs 38, 39, 40).

stigmal opening (Fig. 34). The apical pore field is composed of round porelli that are both physically separated and morphological distinct from the areolae (Figs 34, 36). The headpole looks blunt, where the interface between the valve face and mantle is abrupt (Figs 34, 35). The raphe bends onto the mantle, and bisects a group of porelli-like pores that are both physically separate and morphologically differentiated from the areolae (Figs 34, 36). Porelli extend from the valve face onto the mantle (Figs 34, 36, 40). Internally, the proximal raphe ends are broadly recurved on a central nodule that appears composed of two internally-elevated sections. Between the sections is situated a rounded stigmal opening (Figs 37, 38). Along the mantle on each side is a marginal lamina (Fig. 38). Helictoglossae are relatively large, and the 
one positioned at the headpole is usually offset from the raphe branch (Fig. 37). Pseudosepta are visible at each pole (Fig. 37).

In girdle view the mantle has round porelli randomly distributed across it. Bands are of the open type, with the closed ends also bearing septa (Figs 39, 40). The bands follow the valve outline in girdle view.

This taxon resembles Gomphonema kaznakowi Meresch. in that the headpole looks similar in structure to the footpole. In both G. kaznakowi and G. difformum, the headpole striae are physically separated from the striae. In G. difformum, the headpole has porelli-like openings, very similar to the porelli of the apical pore field at the footpole; this condition is not seen in G. kaznakowi (Kociolek 1996; Li et al. 2006).

ECOLOGY: Gomphonema difformum is known only from the type locality. This species is present throughout the year with relative abundance of $20 \%$ and less. This species occurred in a stream with neutral $\mathrm{pH}(7.16 \pm 0.27)$, poor nutrients (Phosphate: $0.04 \pm$ $0.02 \mathrm{mgl}^{-1}$; Nitrates: $0.29 \pm 0.37 \mathrm{mgl}^{-1}$ ) and conductivity between $79.71 \pm 11.12 \mu \mathrm{Scm}^{-1}$ (see Table 2). The land cover in the catchment is characterized with wet evergreen to semi-evergreen forest type with moderate agricultural activities.

Gomphonema diminutum Karthick \& Kociolek, sp. nov.

Figs 41-51

DESCRIPTIO: Valvae anguste lineares-clavatae apicibus rotundatibus. Longitudo 21-27 $\mu$ m. Latitudo 3-4 $\mu \mathrm{m}$. Area axialis angusta linearis. Area centralis indistinctis. Raphe lateralis undulata. Externum orificium stigmatis rotundatis. Area apicalis porellorum distincta bilobata. Septa et pseudosepta praesentia ad polos.

DESCRIPTION: Valves narrowly linear-clavate with apices rounded. Length 21-27 $\mu \mathrm{m}$, breadth 3-4 $\mu \mathrm{m}$. Axial area narrow, linear. Central area indistinct. Raphe lateral, undulate. External proximal raphe ends dilated. A round stigmal opening is present. Striae are parallel to radiate, $16-17 / 10 \mu \mathrm{m}$. Apical pore field evident, bilobed. Septa and pseudosepta are present at the poles.

HoLOTYPE: CESH-5-1871, Centre for Ecological Science Herbarium Diatom Collection, Indian Institute of Science, Bangalore, INDIA

Isotypes: BM 101394, The Natural History Museum, Department of Botany, London, UK. Diatom Collection, University of Colorado, Bolder, USA

TyPe LocaltTy: A Stream at Kammani (14²42'47.52"N-74³5'44.988"E); Altitude $109 \mathrm{~m}$ asl, a tributary Bedthi River. Uttara Kannada District, Karnataka, India. (leg. Karthick, B. and D.M.Vishnu, January, 2006).

EтyмоLogy: The species is named for its small size.

In the SEM, the valve exterior has areolae that are slit- or c-shaped on the valve face, but on the mantle striae are composed of two rows of rounded areolae (Figs 47, 48). The raphe appears slightly undulate with enlarged proximal raphe ends. A small, round external stigmal opening is present in the central area (Figs 47, 48). At the footpole, the apical pore field is physically offset from the areolae by a hyaline border. Porelli are round, sembling in size and shape the last stria near the hyaline area. At the headpole areolae are rounded and in double rows, like those on the mantle (Figs 47 and 49). Internally, the central nodule is bilobed, hosting the broadly recurved proximal raphe ends. In the middle of the central nodule is placed an 

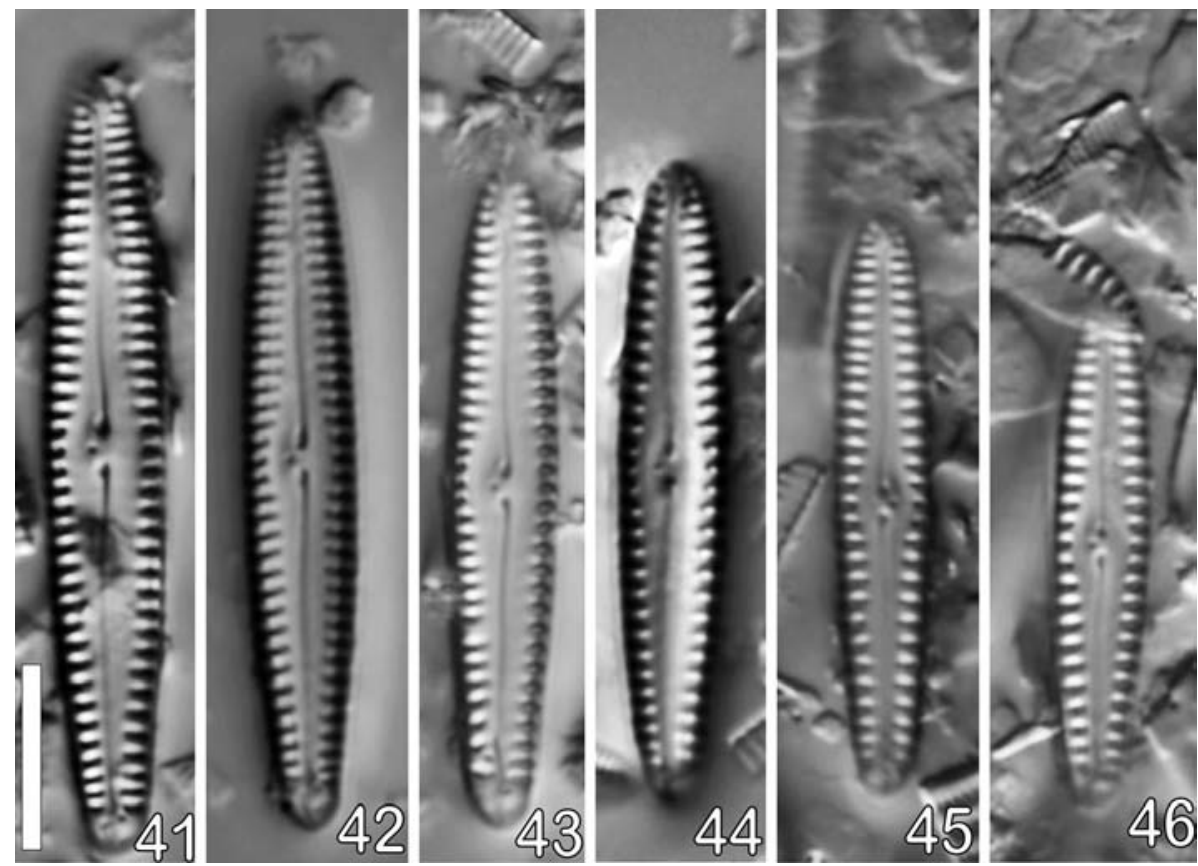

Figs 41-46. LM of Gomphonema diminutum, from the type population; valve view showing the size diminution series. Scale bar represents $10 \mu \mathrm{m}$.

ellipsoidal stigmal opening (Fig. 51). Marginal laminae are present on each side of the valve (Fig. 51). Helictoglossae at the headpole and footpole are offset from the raphe branches. Pseudosepta are present at the poles (Fig. 51).

In girdle view the mantle of the valve has striae with areolae that terminate as slits or in double rows of punctate striae. Striae have round areolae at the headpole (Fig. 49). At the footpole the round apical pore field porelli extend onto to the end of the mantle (Fig. 50). Girdle bands are of the open type, following the contour of the valve. Closed ends of the bands possess septa.

Gomphonema diminutum resembles G. incognitum Reichardt, Jüttner \& Cox in Jüttner et al. (2004, p. 245) in size range and having a wide axial area. The species from India is linear in shape, is narrower and has finer striae than the species described from Nepal. Superficial resemblance in terms of having a broad axial area exists between G. diminutum and G. schweickerdtii Cholnoky (which was, in part, recently suggested to be conspecific with $G$. clevei Fricke, Reichardt 2005), but the Indian species is longer but narrower than the South African taxon (Cholnoky 1953).

ECOLOGY: Gomphonema diminutum was found in many central Western Ghats Rivers. This species was present throughout the year with relative abundance ranging from 20-40\%. This species occurred in a stream with circumneutral $\mathrm{pH}(7.08 \pm 0.17)$, poor nutrients (Phosphate: $0.04 \pm 0.02 \mathrm{mgl}^{-1}$; Nitrates: $0.29 \pm 0.37 \mathrm{mgl}^{-1}$ ) and 


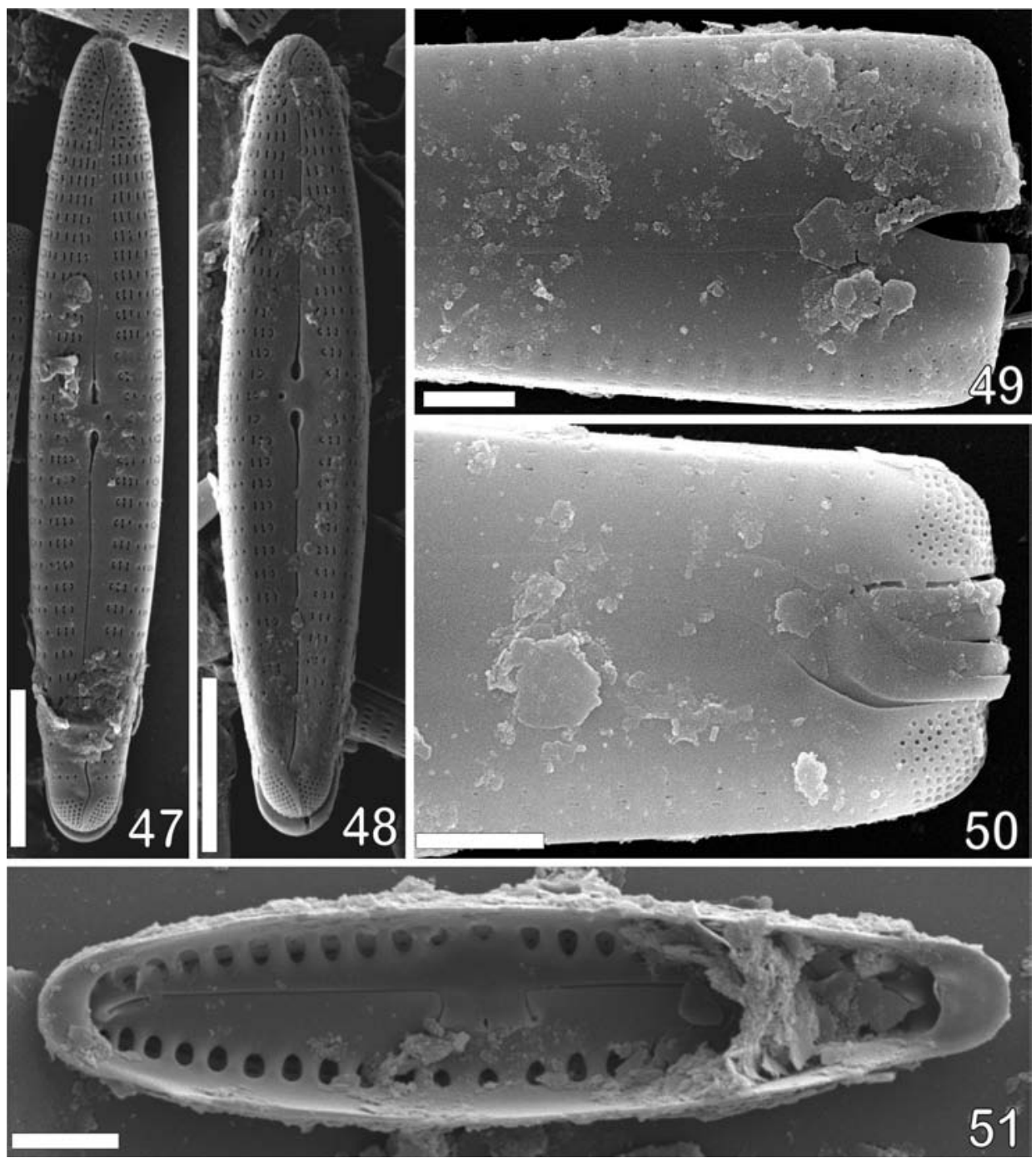

Figs 47-51. SEM. Exterior, Interior, Girdle view of whole valve of Gomphonema diminutum. Figs 47-48. Exterior view of whole valve showing slit or c-shaped areolae, mantle striae with two rows of rounded areolae, hyaline border, a stigmal opening and proximal raphe ends. Fig. 49. Girdle view of the valve showing doubly punctate striae with rounded areolae at headpole. Fig. 50. Girdle view of the valve showing open type girdle bands and closed ends of bands with septa. Fig 51. Internal view of the valve showing central nodule with stigmal opening, marginal laminae, pseudosepta and helictoglossae at both the poles. Scale bar represents $5 \mu \mathrm{m}$ (Figs 47, 48); $2 \mu \mathrm{m}$ (Fig. 51); $1 \mu \mathrm{m}$ (Figs 49, 50).

conductivity between $89.86 \pm 26.18 \mu \mathrm{Scm}^{-1}$ (see Table 2 ). The land cover in the catchment is characterized with wet evergreen to semi-evergreen forest type with the least agricultural disturbance. 


\section{Discussion}

Our work on the present group of species contributes to a growing opinion that endemism in freshwater diatoms, particularly those based in Southern Hemisphere locations, may be much more common than was previously thought (e.g., Mann \& Droop 1996, Mann 1999, Kociolek \& Spaulding 2000, Kociolek \& Stoermer 2001, Kilroy et al. 2003, Vanormelingen et al. 2008). However, recent taxonomic work on selected diatom taxa from Himalayas (Jüttner et al. 2004) and the current study has led to the recognition of an increasing number of endemic taxa in the freshwater diatom flora of the Indian subcontinent, particularly biodiversity hotspots like Western Ghats and Eastern Himalayas. Based on unpublished work by Karthick (Ph.D. Dissertation on Ecology of Stream Diatom Community in Central Western Ghats, to be submitted to Mysore University), some of the Gomphonema species found in the Western Ghats are widespread on other continents, but a few others, particularly those in streams of Western Ghats, seem to have limited geographical distributions. India has a diverse flora, but there is still a lot to do to document and create a more substantial understanding of this large and complex country. The three new species presented here occur in several environments, and are the dominants or represent a large proportion of the diatoms present in the collections. While there have been many (over 100) Gomphonema taxa reported from India, it still does not approach the number recorded from the intensely studied continent of Europe (e.g. Krammer \& Lange-Bertalot 1986, e.g. Reichardt 1999) or the little studied country of the USA (Kociolek 2005, lists 237 Gomphonema taxa reported in the literature).

Of the three new species, G. difformum is quite different from almost all other Gomphonema species. Of particular note is the presence of what appears to be apical pore fields at both the headpole and footpole. Our observations illustrate at the headpole, groups of pores on the mantle at either side of the external distal raphe end that are separate from and quite dissimilar to the areolae. Their oblong to rounded appearance is more similar to the porelli of the apical pore fields at the footpole than the slit-like areolae found in G. difformum. Structures similar to apical pore fields at the headpole are also seen in G. kaznakowi, described from high mountain sites from China (Mereschkowsky 1906). Kociolek (1992) showed with electron microscopy that hyaline areas at the headpole of this species were composed of densely arranged areolae, that were physically separate from valve face areoale, but not structurally differentiated from nor more compact (at least in terms of the porelli found at the footpole) than the valve areolae. Gomphonema difformum differs from G. kaznakowi by a number of features, most notably by possessing a stigma and having external proximal raphe ends that are quite dilated. Gomphonema gandhii has a unique feature, namely the presence of a hood or siliceous fold over the central nodule, the edge of which is suggestive of the internal proximal raphe ends. In this feature it looks very similar to Gomphocymbella species from the East African Rift Valley lakes (Kociolek $\&$ Stoermer 1993); the feature is found in no other freshwater gomphonemoid diatoms. Gomphonema diminutum seems to be closely allied with species described from the Himalayas, though more work is necessary to affirm their relationships. For example, though not described nor illustrated in the original work, it appears that the Himalayan species do have both septa and pseudosepta. These features have been overlooked by 
many students of the genus Gomphonema (e.g. Patrick in Patrick \& Reimer 1966, Reichardt 2005, 2007). These similarities with species from a variety of areas support the idea of biogeographic distributions that have a phylogenetic basis. Williams \& Reid (2006) have addressed this issue amongst the Eunotioid diatoms. These three new species occur in oligotrophic, low conductivity, $\mathrm{pH}$ neutral water, whereas the commonly reported Gomphonema species in Southern India, such as G. parvulum, G. gracile, G.affine, and G. pseudoaugur, occur in eutrophic, alkaline and high conductivity, waters. The distribution ranges of all three species were restricted to Western Ghats streams; hence these three species appear to be endemic to Western Ghats. However studies on diatoms in peninsular India are meager and it is too early to comment on the distribution of these species.

A phylogenetic analysis based on morphological data is necessary to further confirm the relationships of these three taxa with African and Himalayan taxa. The data from fossil and contemporary faunas indicate that, throughout the late Cretaceous, India maintained biological exchanges with adjacent lands (Briggs 2003). This could be a reason for these species connection with the African and Himalayan species. The biotic components of Africa, Madagascar and Western Ghats have inspired centuries of speculation relating to the mechanisms by which these biotas came to reside in these regions, and regarding their commonalities. Most of the authors claim that the most probable causal factors are Gondwanan vicariance and/or Cenozoic dispersal (Yoder \& Nowak 2006). It would be interesting to study further on diatom flora of Western Ghats in detail and compare them with Indian Ocean islands and African species to elucidate their biogeographic history.

While recent researches on diatom taxonomy from tropical regions are challenging the ubiquity hypothesis for diatoms, they also seem to confirm that diatom communities are controlled by the same processes affecting macro-organisms in a different scale (Vanormelingen et al. 2008). These studies therefore also highlight the need for conservation and the protection of unique and isolated areas, such as Western Ghats, against habitat alterations and introduction of exotic species. Thus, it is important for future studies of diatom biodiversity to include the mechanisms generating diatom species diversity and distributions. Previous reports of Gomphonema taxa from Western Ghats are from light microscope observations and therefore are subject to further verification. The current report improves our knowledge of status, and phylogentic relation of Gomphonema and the biodiversity of freshwater diatoms of Western Ghats. These current results underscore the pressing need to continue research into diatom taxonomy and ecology in least explored geographical zone on earth particularly southern hemisphere.

\section{Acknowledgements}

We thank SEM facility at University of Colorado's Nanomaterials Characterization Facility and Indian Institute of Science-Nanoscience Initiative. We are grateful to Indian Institute of Science, Ministry of Science and Technology and The Ministry of Environment and Forests, Govt. of India for the financial support and the Principal, Yuvaraja's College, Mysore, for encouragement. We thank Sameer, Vishnu, Shrikant, Sudhira, Gururaja, Alakananda and Supriya of CES, IISc, Bangalore for active interactions in the field and laboratory. 


\section{References}

ABDUL-MAJEED, M. (1935): Freshwater algae of the Punjab, Pt. I. Bacillariophyta (Diatomeae). - Punjab University Publications, Lahore.

APHA. (2005): Standard Methods for the Examination of Water and Wastewater (21 ${ }^{\text {st }}$ Edition), American Public Health Association, Washington DC, USA.

BISWAS, K. (1936): Common diatoms of the Loktak Lake, Manipur, Assam. - J. Asiat. Soc. Beng. 2(2): $171-175$.

BOSSUYT, F. \& M.C. MILINKOVITCH (2001): Amphibians as indicators of early tertiary 'out-ofIndia' dispersal of vertebrates. - Science 292: 93-95.

BRIGGS, J.C. (2003): The biogeographic and tectonic history of India. - J. Biogeogr. 30:381-388.

CARTER, N. (1926): Fresh water algae from India. - Records Bot. Surv. India. 9: 263-302.

CHOLNOKY, B.J. (1953): Diatomeenassoziation aus dem Hennops-rivier bei Pretoria. - Verh. Zool.-Bot. Ges. Wien 93: 134-149.

COMPÈRE, P. (1995): Gomphonema zairense sp. nov. from the Tshopo waterfalls (Kisangani, Zaire). - Diatom Res. 10: 31-37.

Conservation International; MARK MCGINLEY (Topic Editor). (2008): Biological diversity in the Western Ghats and Sri Lanka. - In: Encyclopedia of Earth. Eds. Cutler J. Cleveland (Washington, D.C.: Environmental Information Coalition, National Council for Science and the Environment). [Online]. 01 September 2009. Available from:http://www.eoearth.org/article/Biological_diversity_ in_the_Western_Ghats_and_Sri_Lanka

DE TONI, J.B. (1891-94): Sylloge Algarum Omium Hueusque Cognitarum, 2, pts 1-3.

DICKIE, G. (1882): Notes on algae from Himalayas. - Bot. J. Linn. Soc. 19: 230.

EHRENBERG, C.G. (1845): Diatoms from Calcutta (as given by SKVORTZOW, 1935. Diatoms from Calcutta, India. - Phil. J. Sci. 58: 179-192.

FOURTANIER, E. \& J.P. KOCIOLEK (2009): Catalogue of Diatom Names. [On-line Version]. California Academy of Sciences. 01 September 2009. Available from: http://research.calacademy.org/ research/diatoms/names/index.asp

FRICKE, F. (1904): Plates 245-252. - In A. SCHMIDT [ed.], Atlas der Diatomaceenkunde. Leipzig. O.R. Reisland.

GANDHI, H.P. (1955): A contribution to our Knowledge of the freshwater diatoms of Pratapgarh, Rajasthan. - J. Indian Bot Soc. 34: 304-338.

GANDHI, H.P. (1956): A contribution to the freshwater Diatomaceae of S. Western India - I. Freshwater diatoms of Dharwar. - J. Indian Bot Soc. 35: 194-202.

GANDHI, H.P. (1957a): The freshwater diatoms from Radhanagari - Kolhapur. - Ceylon J. Sci (Biol. Sect) 1: 45-47.

GANDHI, H.P. (1957b): Some common freshwater diatoms from Gersoppa falls (Jog falls). - J. Poona Univ. Sci. Sect. 12: 13-21.

GANDHI, H.P. (1958a): Freshwater diatoms from Kolhapur and its immediate environs. - J. Bombay Nat. Hist. Soc. 55: 493-511.

GANDHI, H.P. (1958b): The freshwater diatoms flora of the Hirebhasgar Dam area, Mysore State. - J. Indian Bot Soc. 37: 249-265.

GANDHI, H.P. (1959a): The freshwater diatom flora from Mugad, Dharwar District with some ecological notes. - Ceylon J. Sci. (Biol. Sect.) 2: 98-116. 
GANDHI, H.P. (1959b): Freshwater diatoms from Sagar in the Mysore State. - J. Indian Bot Soc. 38: $305-331$.

GANDHI, H.P. (1959c): Freshwater diatom flora of the Panhalgarh Hill Fort in the Kolhapur district. - Hydrobiologia 14: 93-129.

GANDHI, H.P. (1960a): The diatom flora of the Bombay and Salsette Islands. - J. Bombay Nat. Hist. Soc. 57: 7-123.

GANDHI, H.P. (1960b): On the diatom flora of some ponds around Vasna village near Ahmedabad. - J. Indian Bot Soc. 39: 558-567.

GANDHI, H.P. (1962a): Some freshwater diatoms from Lonawala Hill Station in the Bombay state (Maharashtra). - Hydrobiologia 20: 128-154.

GANDHI, H.P. (1962b): Notes on the Diatomaceae from Ahmedabad and its Environs- IV. The diatom communities of some freshwater pools and ditches along Sarkhej road. - Phykos 1: 115-127.

GANDHI, H.P. (1964): Notes on Diatomaceae of Ahmedabad and its Environs V. The diatoms flora of Chandola and Kankaria Lakes. - Nova Hedwigia 8: 347-402.

GANDHI, H.P. (1966): Freshwater diatom flora of Jog falls, Mysore State. - Nova Hedwigia 11: 89-197.

GANDHI, H.P. (1967): Notes on Diatomaceae from Ahmedabad and its environs. VI. On some diatoms from fountain reservoirs of Seth Sarabhai’s Garden. - Hydrobiologia 30: 248-272.

GANDHI, H.P. (1970): A further contribution to the diatom flora of the Jog falls, Mysore state. - Nova Hedwigia 31: 633-352.

GANDHI, H.P. (1998): Freshwater Diatoms of Central Gujarat with a Review and Some Others. - Bishen Singh Mahendra Pal Singh. Dehra Dun.

GANDHI, H.P., D.J. MOHAN \& A.B. VORA (1983): Preliminary observation on Baltal and Ara sediments, Kashmir. - Proc. X Ind. Coll. Micropal. \& Strat. 555-570

GANDHI, H.P., A.B. VORA \& D.J. MOHAN. (1985): Fossil diatoms from Baltal, Karewa Beds, Kashmir - In: AGRAWAL, D.P., S. KUSUMGAR \& R.K. KRISHNAMURTHY (eds.); Climate and geology of Kashmir, the last 4 million years. Current trends in Geology, Today and Tomorrow's Printers and Publishers. New Delhi.

GRUNOW, A. (1865): Über die von Herrn Gerstenberger in Rabenhorst's Decaden ausgegeben Süsswasser Diatomaceen und Desmidiaceen von der Insel Banka, nebst Untersuchungen über di Gattungen Certaoneis und Frustulia. - In: Rabenhorst, L., (ed.), Beiträg zur näheren Kenntinis und Verbreitung der Algen. II: 1-16. Edward Kummer.

HUSTEDT, F. (1922): Bacillariales aus Innerasien. Gesammelt von Dr. Sven Hedin. - In: HEDIN, S. (ed.): Southern Tibet, discoveries in former times compared with my own researches in 1906-1908. 6(3):107-152. Lithographic Institute of the General Staff of the Swedish Army, Stockholm.

HUSTEDT, F. (1942): Süßwasser-Diatomeen des indomalayischen Archipels und der Hawaii-Inslen. - Int. Rev. ges. Hydrobiol. Hydrograph. 42: 1-252.

HUSTEDT, F. (1945): Diatomeen aus Seen und Quellgebieten der Balkan-Halbinsel. - Arch. Hydrobiol. 40: 867-973.

HUSTEDT, F. (1949): Süsswasser-Diatomeen aus dem Albert-Nationalpark in Belgisch-Kongo. Exploration du Parc National Albert, Mission H. Damas (1935-1936) - Institut des Parcs Nationaux du Congo Belge, Bruxelles.

INGER, R.F. (1999): Distribution of amphibians in Southern Asia and adjacent islands - In DUELLMAN, W.E. (ed.): Patterns of Distribution of Amphibians: A Global Perspective. Johns Hopkins University Press. Baltimore. 
JÜTTNER, I., E. REICHARDT \& E.J. COX (2004): Taxonomy and ecology of some new Gomphonema species common in Himalayan streams. - Diatom Res. 19: 235-264.

KILROY, C., K. SABBE, E.A. BERGEY, W. VYVERMAN \& R. LOWE (2003): New species of Fragilariforma (Bacillariophyceae) from New Zealand and Australia. - N.Z. J. Bot. 41:535-554.

KOCIOLEK, J.P. (1992): Valve ultrastructure and systematic position of Gomphonema kaznakowi Mereschkowsky. - Diatom Res. 7: 259-265.

KOCIOLEK, J.P. (1996): Taxonomic instability and the creation of Naviculadicta Lange-Bertalot in Moser \& Lange-Bertalot, a new, catch-all genus of diatoms. - Diatom Res. 11: 223-224.

KOCIOLEK, J.P. (2005): A Checklist and Preliminary Bibliography of the Recent, Freshwater Diatoms of Inland Environments of the Continental United States. - Proc. Calif. Acad. Sci. 56: 395-525.

KOCIOLEK, J.P. \& J.C. KINGSTON (1999): Taxonomy, ultrastructure, and distribution of some gomphonemoid diatoms (Bacillariophyceae: Gomphonemataceae) from rivers in the United States. - Can. J. Bot.77: 686-705.

KOCIOLEK, J.P. \& S.A. SPAULDING (2000): Freshwater diatom biogeography. - Nova Hedwigia 71: 223-241.

KOCIOLEK, J.P., S.A. SPAULDING, K. SABBE \& W. VYVERMAN, W. (2004): New Gomphonema Ehrenberg (Bacillariophyta) species from Tasmania. - Phycologia 43: 427-444.

KOCIOLEK, J.P. \& E.F. STOERMER (1991): New and interesting Gomphonema (Bacillariophyceae) species from East Africa. - Proc. Proc. Calif. Acad. Sci. 47: 275-288.

KOCIOLEK, J.P. \& E.F. STOERMER (1993): The diatom genus Gomphocymbella O. Müller: Taxonomy, ultrastructure and phylogenetic relationships. - Nova Hedwigia Beih 106: 71-91.

KOCIOLEK, J.P. \& E.F. STOERMER (2001): Taxonomy and ecology: a marriage of necessity. - Diatom Res. 16: 433-442.

KRAMMER, K. \& H. LANGE-BERTALOT (1986): Bacillariophyceae. 1. Teil: Naviculaceae - In ETTL, H., J. GERLOFF, H. HEYNIG \& D. MOLLENHAUER (eds.) Süsswasserflora von Mitteleuropa, Band 2/1. Gustav Fischer Verlag: Stuttgart, New York.

KRISHNAMURTHY, V. (1954): A contribution to the Diatom flora of South India. - J. Indian Bot Soc. 33(4): 354-81.

KUMAWAT, D.A., Y.P. MALCHE, H.E. RANE, S.B. PATIL, R.B. BORSE \& S.D. VANJARI (2008): Diatoms from Southern Satpura Hill Ranges of Maharashtra. Genus - Gomphonema Agardh. - J. Indian Bot Soc. 87(1\&2):61-66.

LANGE-BERTALOT, H. \& S.I. GENKAL (1999): Diatoms from Siberia I - Islands in the Arctic Ocean (Yugorsky-Shar Strait). - Iconogr. Diatomol. 6:1-303.

LI, Y.L., X. GONG, P. XIE \& J. SHEN (2006): Distribution and morphology of two endemic gomphonemoid species, Gomphonema kaznakowi Mereschkowsky and G. yangtzensis Li nov. sp. in China. - Diatom Res. 21: 313-324.

LI, Y., J.P. KOCIOLEK \& D. METZELTIN (In Press): Gomphonema sichuanensis Li and Kociolek sp. nov. and Gomphonema laojunshanensis Li, Kociolek and Metzeltin sp. nov. from two high mountain lakes, China. - Diatom Res.

MANN, D.G. (1999): The species concept in diatoms. - Phycologia 38: 437-495.

MANN, D.G. \& S. DROOP (1996): Biodiversity, biogeography and conservation of diatoms. - Hydrobiologia 336: 19-32.

MEISTER, F. (1932): Kieselalgen aus Asien. Gebruder Borntraeger, Berlin.

MERESCHKOWSKY, C. (1906): Gesetze des Endochroms. Tipo-litografiya Imperatorskago Universiteta, Kazan. 402 pp. 
METZELTIN, D. \& H. LANGE-BERTALOT (1998): Tropical diatoms of South America I: About 700 predominantly rarely known or new taxa representative of the neotropical flora. - Iconogr. Diatomol. 5: $1-695$.

METZELTIN, D. \& H. LANGE-BERTALOT (2007): Tropical diatoms of South America II. Special remarks on biogeography disjunction. - Iconogr. Diatomol. 18:1-877.

MYERS, N., R.A. MITTERMEIER, C.G. MITTERMEIER, G.A.B. DAFONSECA \& J. KENT (2000): Biodiversity hotspots for conservation priorities. - Nature 403: 853-858

PATRICK, R. \& C.W. REIMER (1966): The diatoms of the United States, exclusive of Alaska and Hawaii, Volume 1-Fragilariaceae, Eunotiaceae, Achnanthaceae, Naviculaceae. - Acad. Nat. Sci. Phil. Monograph No. 13, 688 pp.

PRASAD, B.N \& M.N. SRIVASTAVA (1985): Fresh Water Algal Flora of Andaman and Nicobar Islands, Vol .I. - Bishen Singh Mahendra Pal Singh. Dehra Dun.

REICHARDT, E. (1999): Zur Revision der Gattung Gomphonema. Die Arten um G. affine/insigne, G. angustatum/micropus, G. acuminatum sowie gomphonemoide Diatomeen aus dem Oberoligozan in Bohmen. - Iconogr. Diatomol. 8: 1-203.

REICHARDT, E. (2005): Die Identität von Gomphonema entolejum Østrup (Bacillariophyceae) sowie Revision ähnlicher Arten mit weiter Axialarea. - Nova Hedwigia 81: 115-144.

REICHARDT, E. (2007): Neue und wenig bekannte Gomphonema-Arten (Bacillariophyceae) mit Areolen in Doppelreihen. - Nova Hedwigia 85: 103-137.

ROSS, R., E.J. COX, N.I. KARAYEVA, D.G. MANN, T.B.B. PADDOCK, R. SIMONSEN \& P.A. SIMS (1979): An amended terminology for the siliceous component of the diatom cell. - Nova Hedwigia 64, pp. 513-533.

SARODE, P.T. \& N.D. KAMAT (1980): The diatom flora of Nagpur, India. - Nova Hedwigia 32: $797-838$.

SARODE, P.T. \& N.D. KAMAT (1983): Diatoms of Marathwada, Maharashtra - III. - Phykos 22: $26-32$.

SARODE, P.T. \& N.D. KAMAT (1984): Freshwater diatoms of Maharashtra. Saikripa Prakashan. Aurangabad.

SINGH, C.S. (1961): A systematic account of freshwater diatoms of Uttar Pradesh- II. Diatom flora of the Banaras Hindu University. - Proc. Natl. Acad. Sci. India 31: 203-223

SINGH, C.S. (1962): A systematic account of freshwater diatoms of Uttar Pradesh- I. Diatom flora of the Banaras Hindu University. - Proc. Natl. Acad. Sci. India 31: 233-241.

SINGH, C.S. (1963): A systematic account of the freshwater diatoms of Uttar Pradesh III, DiatomFlora of the Rivers Ganga and Barna at Varnasi. - Proc. Natl. Acad. Sci. India 29B, pp. 622-631.

SKVORTZOW, B.W. (1935): Diatoms from Calcutta, India. - Phil. J. Sci. 58: 179-192

SPAULDING, S.A. \& J.P. KOCIOLEK (1998): New Gomphonema (Bacillariophyceae) species from Madagascar. - Proc. Calif. Acad. Sci.50: 361-379.

SRINIVASAN, K.S. (1965): Indian botany in retrospect with particular reference to algal systematics. - J. Asiat. Soc. 7: 49-78.

SUXENA, M.R. \& V. VENKATESWARLU (1970): Diatoms of the Hot springs of Badrinath, Himalayas. - Nova Hedwigia 31: 633-665.

TAYLOR, J.C., C.G.M. ARCHIBALD \& W.R. HARDING (2007): A Methods Manual for the Collection, Preparation and Analysis of Diatom Samples. - WRC Report No TT 281/07. Water Research Commission, Pretoria. South Africa. 
THOMAS, E.W., J.P. KOCIOLEK, R.L. LOWE \& J.R. JOHANSEN (2009): Taxonomy, Ultrastructure and Distribution of Gomphonemoid Diatoms (Bacillariophyceae) from Great Smoky Mountains National Park (U.S.A.). - Nova Hedwigia Beih. 135: 201-238.

THOMAS, J. \& E.A. GONZALVES (1965a): Thermal algae of Western India, I. Algae of the hot springs at Akloli and Ganeshpuri. - Hydrobiologia 25: 330-340.

THOMAS, J. \& E.A. GONZALVES (1965b): Thermal algae of Western India II. Algae of the hot springs at Palli. - Hydrobiologia 25: 341-351.

THOMAS, J. \& E.A. GONZALVES (1965c): Thermal algae of Western India. III. Algae of the hot spring at Sav. - Hydrobiologia 26: 21-28.

THOMAS, J. \& E.A. GONZALVES (1965d): Thermal algae of Western India VII. Algae of the hot spring at Rajapur. - Hydrobiologia 26: 66-71.

VANORMELINGEN, P., E. VERLEYEN \& W. VYVERMAN (2008): The diversity and distribution of diatoms: from cosmopolitanism to narrow endemism. - Biodivers. Conserv. 17: 393-405.

VENKARARAMAN, G, (1957): A Contribution to the Knowledge of the Diatomaceae of Kanya Kumari (Cape Comorin), India. - Proc. Nat. Acad. Sci. India 23B: 80-88

VENKARARAMAN, G. (1956): Contribution to our knowledge of Freshwater diatoms of SouthIndia. Government Press. Madras.

VENKATARAMAN, G. (1939): A systematic account of some S. Indian Diatoms. - Proc. Nat. Acad. Sci. India 24B: 85-197.

WEST, W. \& G.S. WEST (1907): Fresh water algae from Burma including a few from Bengal and Madras. - Ann. Roy. Bot. Gard., Calcutta 6: pt.II.

WILLIAMS, D.M. \& G. REID (2006): Amphorotia nov. gen., a new genus in the family Eunotiaceae (Bacillariophyceae), based on Eunotia clevei Grunow in Cleve \& Grunow. - Diatom Monogr. 6:1-153.

WORLD POPULATION PROSPECTS. (2008): Population Division of the Department of Economic and Social Affairs of the United Nations Secretariat. [Online]. 01 September 2009. Available from: http://esa.un.org/unpp.

YODER, A.D. \& M.D. NOWAK (2006): Has vicariance or dispersal been the predominant biogeographic force in Madagascar? Only time will tell. - Ann. Rev. Ecol. Syst. 37:405-431.

Received 9 October 2009, accepted in revised form 8 January 2010. 